\title{
Luteolysis in the common opossum, Didelphis marsupialis
}

\author{
B. Cook*, F. J. Karsch $\dagger$, Jean W. Graber $\dagger$ and A. V. Nalbandov $\dagger$ \\ *Department of Steroid Biochemistry, University of Glasgow, Royal Infirmary, \\ Glasgow G4 OSF, U.K. and $\uparrow$ Animal Genetics Laboratory, Department of \\ Animal Science, University of Illinois at Urbana-Champaign, Illinois 61801, U.S.A.
}

In many mammalian species, pregnancy triggers a luteotrophic mechanism that causes the corpora lutea (CL) to persist for a period longer than the lifespan of the cyclic CL. In marsupials, however, the life span of $C L$ is not changed by pregnancy. In Didelphis marsupialis, for example, the $C L$ reach maximum size on Day 3 after ovulation, begin to regress on Day 7 and are almost fully regressed by Day 13 when parturition occurs (Hartman, 1923). The next ovulation takes place about Day 28 regardless of whether pregnancy has intervened, provided no young are suckling (Hartman, 1923). Unlike the effects in sheep and some other species (Anderson, Bowerman \& Melampy, 1963), hysterectomy also fails to prolong the life of $C L$ in the opossum (Hartman, 1925) and there appears to be no known way in which the life of the didelphine CL can be extended. Because luteotrophic mechanisms induced by pregnancy and luteolytic mechanisms depending on the uterus seem to be absent in the opossum, the direct action of oestrogen on the lifespan of the opossum CL was investigated. Hoffmann (1960) suggested, as a consequence of his studies in women, that oestrogen acted directly on CL to induce regression, and a direct effect of oestrogen has been demonstrated for the CL of sheep (Cook, Karsch, Foster \& Nalbandov, 1974) and rhesus monkeys (Karsch \& Sutton, 1976).

Table 1. Experimental protocol of the treatments on opossums

\begin{tabular}{|c|c|c|c|c|c|c|c|c|}
\hline \multicolumn{2}{|c|}{ Animal } & \multicolumn{6}{|c|}{ Treatment on Day } & \multirow{2}{*}{$\begin{array}{l}\text { Wt of } \\
\text { ovaries } \\
\text { at death } \\
\text { (mg) }\end{array}$} \\
\hline No. & Wt $(\mathrm{kg})$ & -4 & -2 & 0 & 4 & 24 & 32 & \\
\hline 1 & 1.93 & PMSG* & PMSG* & HCG $\uparrow$ & Killed & - & - & 1176 \\
\hline 2 & $3 \cdot 00$ & PMSG* & PMSG* & HCG $\dagger$ & Laparotomy & Killed & - & 492 \\
\hline 3 & $2 \cdot 03$ & PMSG* & PMSG* & HCG $\dagger$ & $\begin{array}{c}\text { Laparotomy } \\
+X \text {-ray } \neq\end{array}$ & Killed & - & 259 \\
\hline 4 & $2 \cdot 89$ & PMSG* & PMSG* & $\mathrm{HCG} \uparrow$ & $\begin{array}{c}\text { Laparotomy } \\
+ \text { X-ray } \ddagger\end{array}$ & Laparotomy & Killed & 439 \\
\hline 5 & $2 \cdot 45$ & PMSG* & PMSG* & HCG $\dagger$ & $\begin{array}{c}\text { Laparotomy } \\
+ \text { X-ray } f\end{array}$ & $\begin{array}{l}\text { Laparotomy } \\
\text { + oestradiol\$ }\end{array}$ & Killed & 322 \\
\hline
\end{tabular}

* 50 i.u. PMSG (Equinex: Ayerst Labs. Inc.) injected subcutaneously.

† 75 i.u. HCG (Follutein: E.R. Squibb \& Sons) injected intraperitoneally.

$\$ 1500 \mathrm{R}$ to each ovary.

$\$ 4 \mu \mathrm{g}$ oestradiol injected in corn oil into each ovary.

The experimental protocol is shown in Table 1, the method of induction of ovulation being that used by Cook \& Nalbandov (1968). The X-irradiation was carried out exactly as described for rabbits (Keyes \& Nalbandov, 1967) and sheep (Karsch, Noveroske, Roche, Norton \& Nalbandov, 1970). At the second laparotomy, Opossum 5 received an intraovarian injection of oestradiol into each ovary (see Cook et al., 1974). The rationale for the treatments was that (1) X-irradiation would be carried out when the CL were completely formed; (2) X-irradiation would cause destruction of the

$\ddagger$ Present address: Reproductive Endocrinology Program, Department of Pathology, University of Michigan, Ann Arbor, Michigan 48104, U.S.A. 
follicular apparatus, thereby removing the luteolytic influence of the oestrogen secreted by the follicles and permitting the survival of the $\mathrm{CL}$; (3) ovaries would be examined and oestrogen would be administered towards the end of the follicular phase when luteal regression should normally be complete; and (4) the ovaries would be re-examined when the next ovulation should have occurred.

Opossum 1, killed 4 days after injection of HCG, contained normal luteal tissue (PI. 1, Fig. 1), and those of Opossum 2 contained follicles at all stages of development and corpora albicantia (Pl. 1, Fig. 2). The irradiation (Opossums 3, 4 and 5) caused profound follicular destruction but luteal regression was not prevented (PI. 1, Figs 3 and 4). It was therefore impossible to determine the effects of oestrogen on opossum CL as intended. The conclusion that the oestrogen produced in developing follicles does not act directly on the opossum CL to induce regression depends on the untested assumptions that induced $\mathrm{CL}$ in opossums are as resistant to X-rays as are normal $\mathrm{CL}$ in rabbits and sheep, and that the signal for luteolysis is not given before Day 4 . The apparent autonomy of the opossum CL warrants further investigation.

We thank H. S. Ducoff, S. Jayaranan and J. W. Noveroske for help with X-irradiations.

\section{References}

Anderson, L.L., Bowerman, A.M. \& Melampy, R.M. (1963) Neuro-uteroovarian relationships. In Advances in Neuroendocrinology, pp. 345-373. Ed. A. V. Nalbandov. University of Illinois Press, Urbana.

Cook, B. \& Nalvandov, A.V. (1968) The effect of some pituitary hormones on progesterone synthesis in vitro by the luteinized ovary of the common opossum (Didelphis marsupialis virginiana). J. Reprod. Fert. 15, 267-275.

Cook, B., Karsch, F.J., Foster, D.L. \& Nalbandov, A.V. (1974) Estrogen-induced luteolysis in the ewe; possible sites of action. Endocrinology 94, 1197-1201.

Hartman, C.G. (1923) The oestrous cycle in the opossum. Am. J. Anat. 32, 353-395.

HARTMAN, C.G. (1925) Hysterectomy and the oestrous cycle in the opossum. Am. J. Anat. 35, 25-29.
HoffmanN, F. (1960) Untersuchungen uber die hormonale Beeinflussung der Lebensdauer des Corpus Luteum im Zyklus der Frau. Geburtshilfe Frauenheikld. 20, 1153-1159.

KARSCH, F.J. \& SuTtoN, G.P. (1976) An intra-ovarian site for the luteolytic action of estrogen in the rhesus monkey. Endocrinology 98, 553-561.

Karsch, F.J., Noveroske, J.W., Roche, F.J., Norton, H.W. \& Nalbandov, A.V. (1970) Maintenance of ovine corpora Iutea in the absence of ovarian follicles. Endocrinology 87, 1228-1236.

Keyes, P.L. \& Nalbandov, A.V. (1967) Maintenance and function of corpora lutea in rabbits depends on estrogen. Endocrinology 80, 938-946.

\section{EXPLANATION OF PLATE 1}

Sections of the ovaries of common opossums; all to the same magnification-bar in Fig. 1 represents $0.1 \mathrm{~mm}$.

Fig. 1. Ovary of Opossum 1 on Day 4 after HCG injection. Well developed corpora lutea and luteinized follicles are present.

Fig. 2. Untreated ovary from Opossum 2 on Day 24. Follicles at all stages of development are present; corpora lutea have regressed.

Fig. 3. Ovary on Day 24 after X-irradiation on Day 4 (Opossum 3). Follicles have been destroyed and corpora lutea (light areas) have degenerated.

Fig. 4. Ovary on Day 32 after X-irradiation on Day 4 and oestradiol injection on Day 24 (Opossum 5). The corpora lutea had regressed by Day 24 (see Fig. 3), and this ovary was essentially similar to that of the uninjected animal. 
PL.ATL: I
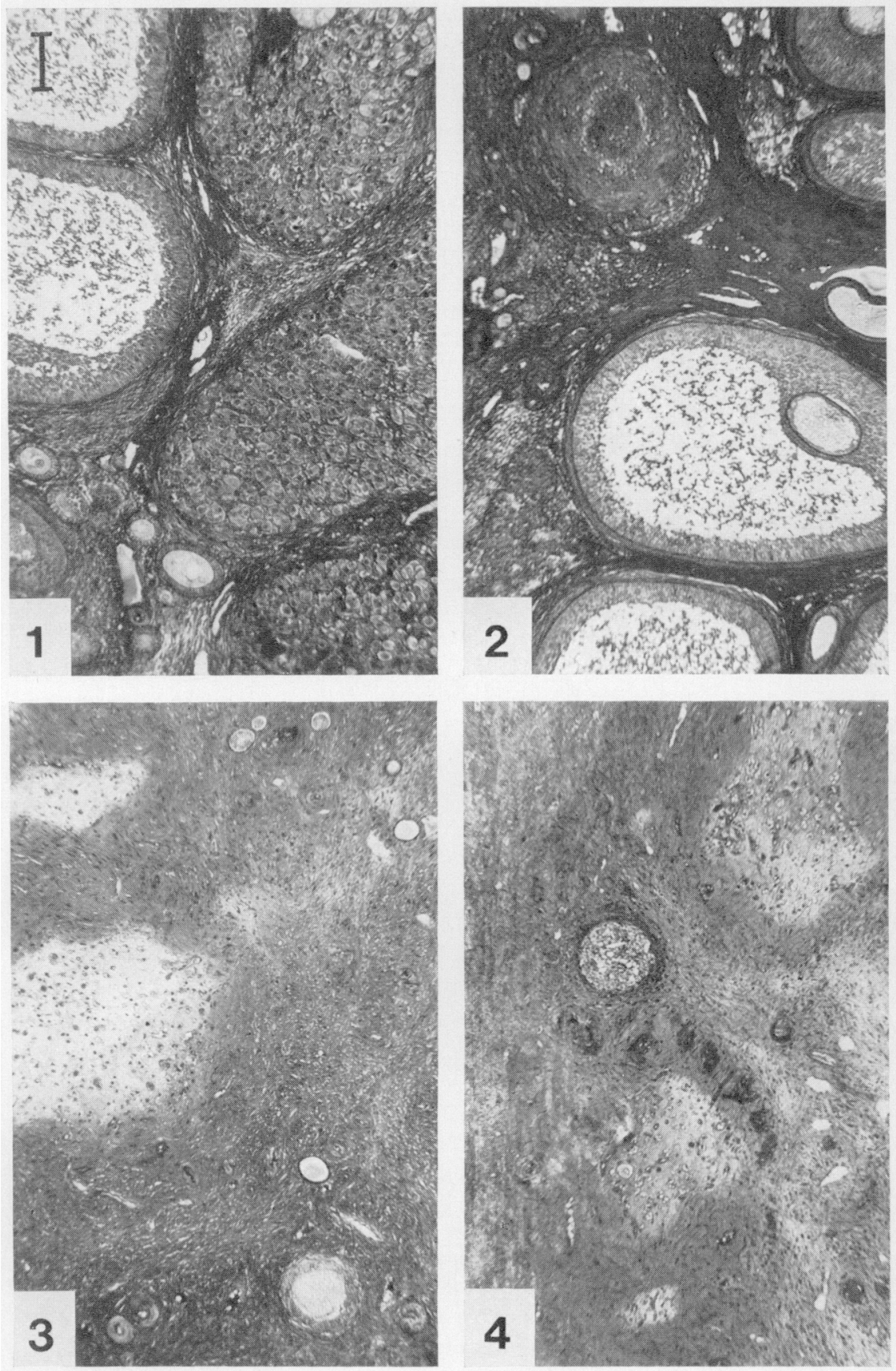